\title{
THE OPINION OF RURAL SCHOOL CHILDREN ABOUT THE DEVELOPMENT OF RURAL AREAS AND SUSTAINABLE MANAGEMENT OPPORTUNITIES IN LATVIA
}

\begin{abstract}
Žanna MARTINSONE, Institute of Occupational Safety and Environmental Health, Rigas Stradins University, 16 Dzirciema Street, Riga, Latvia, LV 1007; zanna.martinsone@ @rsu.lv (corresponding author)

Ivars VANADZIN̦Š, Institute of Occupational Safety and Environmental Health, Rigas Stradins University, Address: 16 Dzirciema Street, Riga, Latvia, LV 1007, ivars.vanadzins@ rsu.lv

The previous survey among adult inhabitants of rural areas indicated that they do not see the possibility for development of business facilities in some rural regions of Latvia - so called specially protected nature territories (SPNT). However, the opinion of the younger generation (pupils of local schools of SPNT) about sustainable management and preservation of the nature has not been analyzed so far. The aim of study was to study the level of social awareness of children living in rural areas on sustainable environment issues. Several discussion-lectures on sustainable environment issues were organized during March-April 2017 in one of SPNT (Raznas National Park; 87 children from 6 to 12 classes were participating). The pupils' opinion on environmental and social awareness indicated that children are more motivated to take active role in protection of environment. Moreover, most of them were aware of the importance of ecosystem services in their lives as well as their impact on nature. It was also found that the interest of children in agriculture derives from their family's core activities in this area indicating that there might be successful future scenarios in this area concentrating on development of ecological and economically sustainable innovative farming. Social innovation labs are very good example on potential scenario that could be repeated also in Latvian rural areas to areas of social actions in order find a better solutions and cope with problems and after all help to successfully generate ideas and implement innovations.
\end{abstract}

Keywords: environmental and social awareness, rural pupils' opinion, sustainable and innovative development.

\section{INTRODUCTION}

Sustainable use of ecosystem services is based on the successful interaction between nature and human beings and person becoming part of ecosystem (at home and work, during recreation etc.). A person's ability to interact with nature (specific ecosystem) is influenced by knowledge and attitude as well as surrounding environment and conditions (quality of life, well-being, etc.) that determine human behavior in particular situations (Atkinson, 2012; Frumkin, 2016; Shigehiro, 2017).

Sensitivity of environment-development conflicts in specially protected nature territories (SPNT) or rural areas represents itself a challenge for sustainable management quests. Appropriate management strategy in Latvia has been proposed by Smart specializations approach. However, its implementation depends to a large extent upon social preconditions. Research demonstrates that specific peculiarities of SPNT life being related to legal framework, infrastructure, demography, historic lifestyle, etc. also mirrors in local social awareness. Of course, social capital play important role for ecological and economic development in rural areas (according to OECD definition social capital is defined as "networks together with shared norms, values and understandings that facilitate co-operation within or among groups) (OECD, 2001). Collective actions (inter-individual collaboration, cooperatives) and learning (knowledge and skills) are basic values for successful development of social capital which is key factor for new innovations (Besser and Miller, 2013; Tregear and Cooper, 2016; Moyes et.al, 2015). Rural areas (especially SPNT) normally have low or limited capacity to develop unique technological or market innovations and thus also social dimensions, including social innovations, should play a critical role (Katonane Kovacs, 2016; Pue et al., 2015) Accordingly, strategic solutions should be focused on social innovation initiatives such us sustainable rural development (land use, mobility concepts and infrastructures, energy efficient restoration; municipal participation; rural quality of life, community centers; neighborhood self-help organizations etc.), demographic change (growing elderly population) and new types of work resources (school-worktransition; youth unemployment; long-term unemployment), municipality (as initiator or partner in projects) (KoSI, 2017). Social innovations could help more successful realization of rural development and growth by replacing governmental involvement and instead building on citizens and enterprises as self-reliant development actors who take change and development into their own hands making up social innovation as important driver for successful rural development and fight against rural marginalization (Neumeier, 2017; Bock, 2016).

Copyright (C) 2017 The Authors. Published by Aleksandras Stulginskis University. This is an open-access article distributed under the terms of the Creative Commons Attribution License (CC-BY 4.0), which permits unrestricted use, distribution, and reproduction in any medium, provided the original author and source are credited. 
In general main reasons for integrating sustainable management and development principles in the long-term strategy of business are related to moral duties and responsibilities for clean environment, the economic and financial advantages gained on the market, and sustainability as key elements of organizational culture.

The perspectives toward eco-innovation are new challenges for central government, local municipalities and society of rural areas where financial and social support statements for each of these actors should be clearly defined (Paraschiv, 2012; Coldwell, 2011). Development, implementation and management of social innovations are challenging, including requirements towards green, inclusive and a smart living therefore there is needs for more effective and transparent governance in general (Hubert, 2012).

In case of Latvia the local self-sustainability should be shifted to low-energy input businesses (including ecotechnological designs), remote jobs (telework), attractive eco-tourism and development of recreational environment, summer-cottage lifestyle, etc. The results of the previous surveys indicated that inhabitants of rural areas prises the value of nature in their place of residence but do not see the possibilities for business development. According to situation analyses in Latvia following social innovations could be developed in rural areas (includes SPNT): sustainable or environment friendly agricultural production; local food systems; social or care farming; social services; renewables (e.g. bioenergy); ecosystem and recreation services; cooperation-networking; local action groups and financial/consulting services, e.g. by using telework opportunities (Melece, 2015).

The social capital and innovations are essential for development of rural areas, therefore young generation (rural schools as platform) is target group for implementation of knowledge, skills for transformation of their attitude and capacity building for creation of a new innovations for successful cooperation and development of local business models (Bargley and Hillyard, 2014). Therefore the opinion of the younger generation (pupils of local schools) about sustainable management and preservation of the local nature resources and use of these resources for potential development of social capital in these rural areas has not been analysed so far.

The aim of this study was therefore to study the level of social awareness of children living in rural areas on sustainable environment issues.

\section{METHODOLOGY}

The study was implemented in collaboration with the University of Daugavpils, "Social, Economic and Humanities Research Institutes" (HESPI) of Vidzeme University and University of Liepaja. The study concentrated on one of the SPNT - Razna National Park (there is no any town - only villages) that is located in economically poorly developed region of Latvia - Latgale. The processes of rural marginalization (limited traditional economic development opportunities and depopulation of this territory because of unemployment, lack of infrastructure etc.) are very important issue in this region. This study describes the situation in Razna National Park that currently is economically poor zone with potential of becoming an excellent platform for creation and implementation of various activities through sustainable innovations as availability of ecosystem services could provide high value for further social innovations. The adults' survey (50 respondents) was performed in this territory during spring (March and April) of 2015. The results showed similarities on scenarios of rural development as seen by respondents but surprisingly most of respondents had no ideas on how to improve their life quality and economical status without direct support from the governmental and municipal authorities. Even if there would be no financial limitations most respondents lacked suggestions on what to do and how to do it. Instead many would choose moving the bigger cities or looking for a job abroad.

During study several discussion-lectures on sustainable environment issues were organized in March and April (2017) with the aim to obtain some feedback and to provide information on how to find resources for e.g. eco - innovations using school children's business start - up program. Two primary schools and two secondary schools that were initially included in this project were located in territory of Razna National Park but one of the secondary schools was not interested in such activity. One of tasks of this study was to obtain questionnaire data on opinion of school children excluding children younger than $6^{\text {th }}$ class due to complexity of some of the questions. Respondents' opinions between primary and secondary schools were not compared because of small number of respondents from $10^{\text {th }}-12^{\text {th }}$ classes. Even if some comparisons could be done to analyse the differences of opinions in age and experience groups of school children but mostly it was planned to compare opinion of school children from different SPNT of Latvia in future. Survey was completed by 87 pupils from $6^{\text {th }}$ to $12^{\text {th }}$ classes in 2 primary schools and 1 secondary school located in this territory ( $67 \%$ were pupil from $6^{\text {th }}-9^{\text {th }}$, and $33 \%$ children from $10^{\text {th }}-12^{\text {th }}$ classes). In this group $61 \%$ of children were girls and $39 \%$ were boys. The range of pupils' age was $12-18$ years and average age was $14.9 \pm 1.5$. Descriptive statistical methods were used: frequency, calculation, cross tabulations was used for data analysis. SPSS 22.0 was used for data analysis and Microsoft Office Excel 2016 for tables and graphics creation.

\section{RESULTS}

In general the children's opinion on environmental and social awareness indicated that they are more motivated to take active role in protection of environment ( $81 \%$ of pupils) even if it is not yet clear what profession they will choose in the future. $4 \%(n=5)$ pupils' mentioned that they will be leaving Latvia after getting profession and $10 \%(n=9)$ pupils answered that they plan to move to bigger cities. Moreover $68 \%(n=59)$ of pupils were aware of the importance of ecosystem services in their lives as well as their impact on nature. 


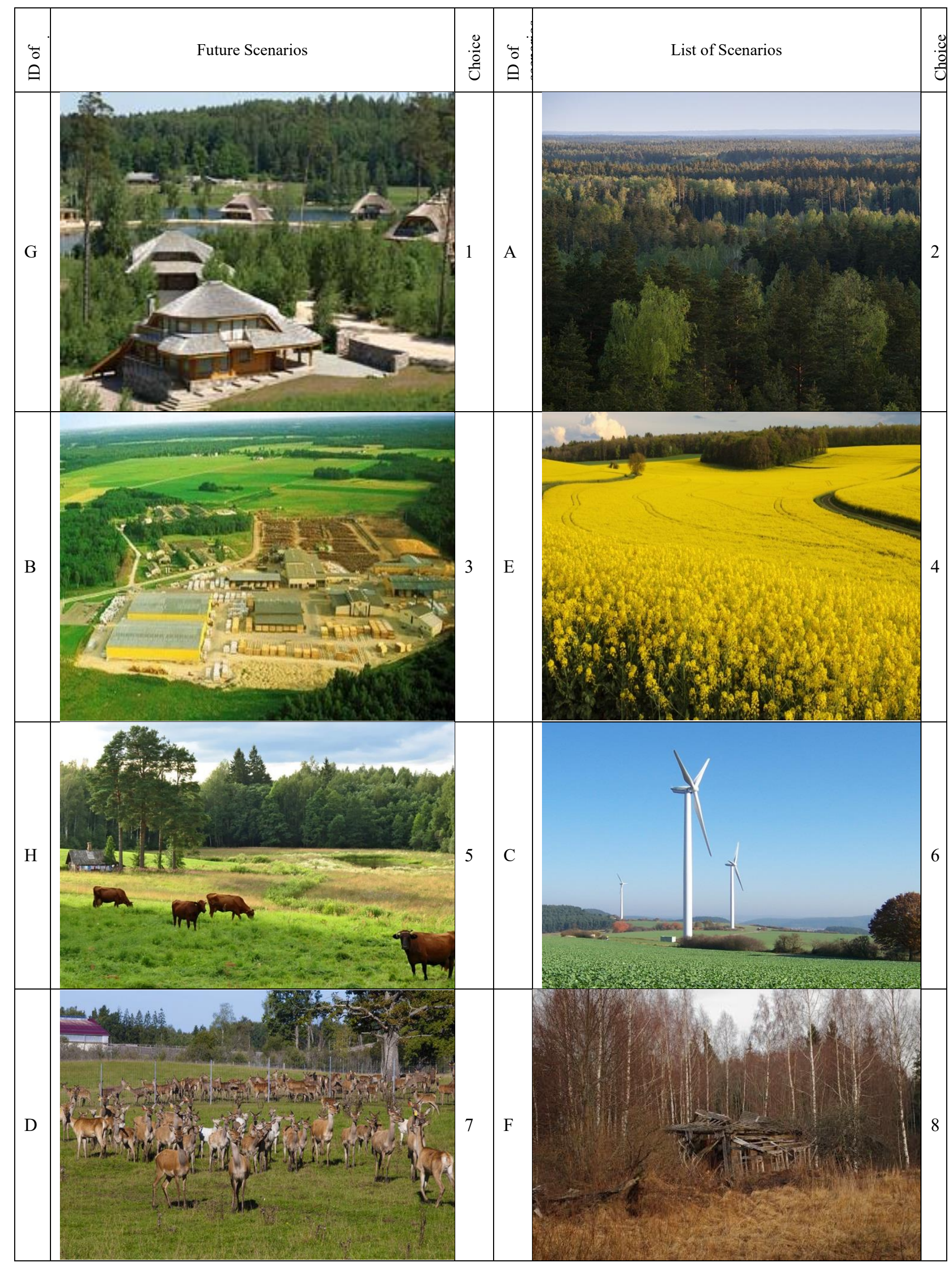

Note: Future scenarios created by HESPI colleagues - Andris Klepers and Iveta Druva-Druvaskalne.

Figure 1. Pupils' choice for scenarios of rural development in their living places after next 50 years. Pictures are ordered according to pupils' choice from 1 (the best scenarios) to 8 (the worst scenarios). Scenarios were ordered from A to F in survey. 
Children were able to appreciate the natural beauty $(74 \% ; n=64)$, clean $(67 \% ; n=59)$ and noise free $(56 \% ; n=49)$ environment and wanted waste free places of residence and surroundings $(87 \% ; n=76)$. Most of them indicated that they intend to keep their family home as a holiday home $(45 \% ; n=39)$ in future to stay in contact with their childhood area. It was also found that the interest of children in agriculture derives from their family's core activities in this area indicating that there might be successful future scenarios in this area concentrating on development of ecological and economically sustainable innovative farming (see Figure 1).

Pupils' choice of future scenarios showed that $1^{\text {st }}$ choice was tourism, eco-villages (social innovations), $2^{\text {nd }}-$ nature (forests, lakes, rivers etc.), $3^{\text {rd }}-$ enterprises (business), $4^{\text {th }}-$ agriculture, $5^{\text {th }}-$ natural landscape (farms), $6^{\text {th }}-$ innovative and eco-technologies, $7^{\text {th }}-, 8^{\text {th }}$ - wild nature. Compared with adults' opinion living in the same territory $\left(1^{\text {st }}\right.$ place - natural landscape (farms), $2^{\text {nd }}-$ agriculture (rape field), $3^{\text {rd }}$ - tourism, eco-villages (social innovations), $4^{\text {th }}-$ innovative farming, $5^{\text {th }}-$ nature (forests, lakes, rivers etc.)), the pupils' opinion was more focused on innovative development of their rural territory and also in increase of social capacity (see Figure 1).

According to pupils' opinion their family business more often were related to agriculture $(30 \% ; n=26)$, then $17 \%(n=15)$ - forestry and only $2 \%(n=1)$ - fishing in this rural area. Mainly agriculture $(41 \% ; n=36)$, forestry $(40 \% ; n=35)$ and fishing $(12 \% ; n=10)$ were mentioned as auxiliary businesses in their families (see Figure 2$)$.

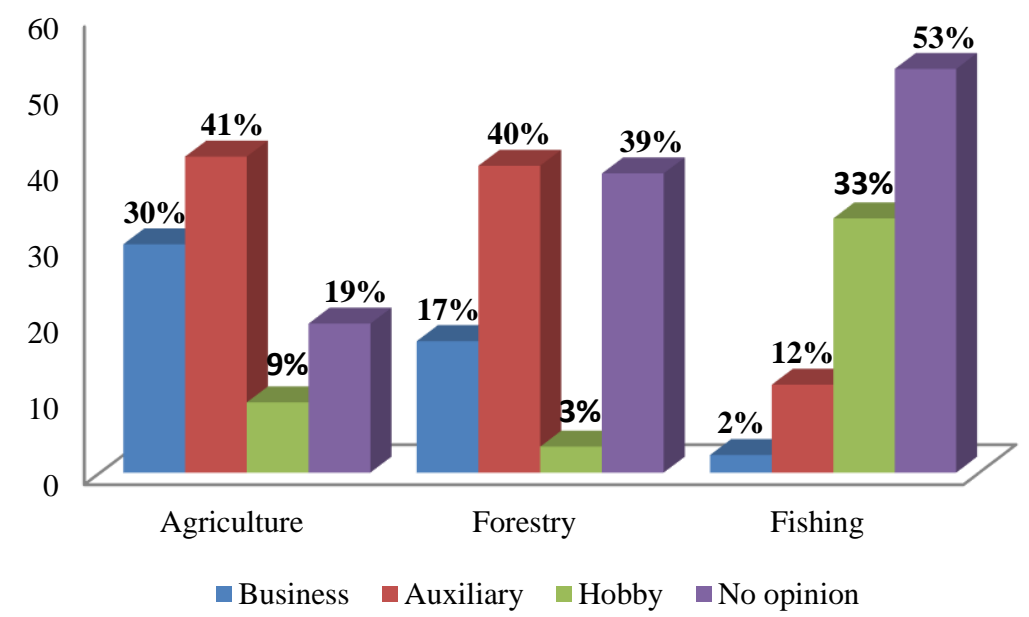

Figure 2. Agriculture, forestry and fishing as main business or auxiliary source of incomes, or hobby among family members according to pupils' opinion.

None of children mentioned countryside tourism as business or auxiliary income source of their families. There was common trend that mainly fishing $(33 \% ; \mathrm{n}=29)$ was mentioned as hobby among family members (see Figure 2).

Pupils' opinion on who is responsible for preserving the values of nature and environment showed that most of them thought of this as responsibility of local municipality $(67 \% ; n=58)$ but some believed that the state, environmental organizations and the municipality $(34 \% ; n=30)$ should be responsible for that.

\section{DISCUSSION AND CONCLUSION}

The young generation is more interested in innovative development of rural territories and mentioned the tourism, eco-villages, enterprises, agriculture as priority and at the same time mentioned the nature and landscape as important part in future scenarios (see Figure 1). It confirms potential resource of social capital and innovations among young generation of this territory and importance of local schools in this process ((Besser and Miller, 2013; Tregear and Cooper, 2016; Moyes et.al, 2015; KoSI, 2017; Howaldt et al. 2014; Papageorgiou, Kyriaki 2017). It is very important not only to create job places or suitable conditions for development of business opportunities and clean environment with good infrastructure but also to think about sport, culture and entertainment events to attract the younger generation to their place of residence instead of leaving. Therefore, municipalities have an important role to play in attracting new, sustainable, well-educated, wellmotivated young people to the rural areas with targeted actions (Bargley and Hillyard, 2014).

Unfortunately the pupils' survey also reflected the situation in the country and especially in this rural region as some children indicated that they have decided to go abroad. Similar opinion was mentioned among adults, too.

Social innovation labs (KoSI, 2017; Howaldt et al. 2014; Papageorgiou, 2017) are very good example on potential scenario that could be repeated also in Latvian rural areas to areas of social actions in order find a better solutions and cope with problems and after all help to successfully generate ideas and implement innovations.

Conclusion. Specially protected nature territories in general and this particular area are very good platform for implementation of local rural development plans taking into account potential resources for social capital and innovations as well as positive opinion of both adult and children on social awareness and on sustainable environment issues. 


\section{ACKNOWLEDGEMENTS}

National Research Programme "Economic Transformation, smart growth, governance and legal framework for the state and society for sustainable development - a new approach to the creation of a sustainable learning community - EKOSOC - LV", Project 5.2.9. "Impact of social awareness changes on sustainable provision of ecosystem services".

\section{REFERENCES}

1. Atkinson, S., Fuller, S., Painter, J. 2012. Well-being and Place. Chaper 1, $1^{\text {st }}$ ed., Ashgate Publishing Ltd.

2. Bagley, C., Hillyard, S. 2014. Rural schools, social capital and the Big Society: a theoretical and empirical exposition. British Educational Research Journal, Vol. 40, No. 1, 63-78, https://doi.org/10.1002/berj.3026

3. Besser, L.T., Miller, J.N. 2013. Social capital, local businesses, and amenities in U.S. rural prairie communities. Journal of Rural Studies, Vol. 32, 186-195. https://doi.org/10.1016/j.jrurstud.2013.06.004

4. Bock, B.B. 2016. Rural Marginalisation and the Role of Social Innovation; A Turn Towards Nexogenous Development and Rural Reconnection, Sociologia RuralisVC2016 European Society for Rural Sociology. Sociologia Ruralis, Vol. 56, No. 4, pp. 552-573, https://doi.org/10.1111/soru.12119

5. Coldwell, D.A.L., Joosub, T., Papageorgiou, E. 2011. Responsible leadership in organizational crises: An analysis of the effects of public perceptions of selected SA business organizations' reputations. Journal of Business Ethics.

6. Frumkin, H. 2016. Environmental Health: From Global to Local. $3^{\text {rd }}$ ed., Jossey-Bass.

7. Howaldt, J., Kesselring, A., Kopp, R., Schwarz, M. 2014. Social Theory. In Jürgen Howaldt, Anna Butzin, Dmitri Domanski, Christoph Kaletka (Eds.): Theoretical Approaches to Social Innovation. A critical literature review. A deliverable of the project "Social Innovation: Driving force of social change" (SI-DRIVE). Dortmund, 9-33. http://www.kosilab.net/files/content/documents/Berichte/KoSILab\%20Report_Social\%20Innovation\%20Labs_final.pdf

8. Hubert, A. 2012. Forward In: Challenge Social Innovation. In: Franz, H.W. et al.(eds.) Challenge social innovation: potentials for business, social entrepreneurship, welfare and civil society. Heidelberg, Springerhttp://www.springerlink.com.ux4118xu6v.useaccesscontrol.com/content/b7k442170m341617/fulltext.pdf

9. Katonane Kovacs, J., Varga, E., Nemes, G. 2016. Understanding the process of social innovation in rural regions: some Hungarian case studies. Studies in Agricultural Economics, Vol. 118, pp. 22-29 http://dx.doi.org/10.7896/j.1604

10. Melece, L. 2015. Social innovations and its types in rural areas. Proceedings of the 2015 International Conference "Economic Science for Rural Development", Latvian State Institute of Agrarian Economics, No 38, pp. 142-153

11. Moyesa, D., Ferrib, P., Hendersonc, F., Whittamd, G. 2015. The stairway to Heaven? The effective use of social capital in new venture creation for a rural business. Journal of Rural Studies, Vol. 39, pp. 11-21, https://doi.org/10.1016/j.jrurstud.2015.02.004

12. Neumeier, S. 2017. Social innovation in rural development: identifying the key factors of success. Geographical Journal, Vol. 183, Iss. 1, pp. 34-46. https://doi.org/10.1111/geoj.12180

13. OECD 2001. The Well-Being of Nations: The Role of Human and Social Capital, OECD, Paris. https://stats.oecd.org/glossary/detail.asp?ID=3560

14. Papageorgiou, K. 2017. Labs for Social Innovation. Available online at https://www.slideshare.net/ESADE/labs-for-socialinnovation-institute-for-social-innovation-esade

15. Paraschiv, D. M., Nemoianu, E. L., Langă, C. A., Szabó, T. 2012. Eco-innovation, Responsible Leadership and Organizational Change for Corporate Sustainability. Amfiteatru Economic Journal, Vol. 14, Iss. 32, pp. 404-419, http://hdl.handle.net/10419/168760

16. Pue, K., Vandergeest, C., Brenitz, D. 2015. Toward a Theory of Social Innovation. Innovation Policy Lab White Paper. No. 201601. Available at Social Science Research Network.

17. Shigehiro, O. 2014. Socioecological Psychology. Annual Review of Psychology, Vol. 65, pp. 581-609. https://doi.org/10.1146/annurev-psych-030413-152156

18. Tregear, A., Cooper, S. 2016. Embeddedness, social capital and learning in rural areas: The case of producer cooperatives. Journal of Rural Studies, Vol. 44, pp. 101-110. https://doi.org/10.1016/j.jrurstud.2016.01.011 